\title{
Fundamentalism and Terrorism
}

\section{by Cassandra Rausch}

\section{(cc) $\mathrm{BY}$}

This work is licensed under a Creative Commons Attribution 3.0 License.

\begin{abstract}
Citizens worldwide are becoming all too familiar with the accelerated frequency of terrorist attacks in the $21^{\text {st }}$ century, particularly with those involving a religious underpinning. Why, though, have religiously-affiliated acts of terrorism become such a common occurrence? By examining how religious fundamentalism has accelerated and intensified terrorism within the modern world, scholars can focus on determining the "why". By historically defining terrorism and fundamentalism and then placing them within the context of current religio-political and socio-political discourse, one can observe the shift from nationalism into terrorism and therefore understanding the innate interconnectedness of fundamentalism and terrorism as a whole.
\end{abstract}

Keywords: religious fundamentalism, terrorism, religious terrorists, modern terrorism, religio-political discourse, socio-political discourse

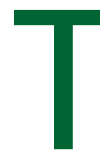

hroughout the beginning of the $21^{\text {st }}$ century, it is no surprise that terrorism has come to be a major concern worldwide. Due to the frequency and magnitude of violence, many scholars have and are trying to determine the sudden surge in activity. Since the Cold War has ended, there seems to be one driving factor behind the atrocities, and focus has shifted from nationalism to religious fundamentalism as the cause of terrorist acts. From the World Trade Center bombings in 1993 and their eventual destruction on September 11th, 2001, suicide attacks in Israel in Palestine, nerve gas in the Tokyo subway, and assassinations in India, Israel, and Algeria, religion has come to the forefront as motivation for the largest terrorist organizations in the modern world (Juergensmeyer, 2001).

In order to examine this phenomenon, one main question must be answered: How has religious fundamentalism accelerated terrorism in the modern world? To establish a framework to respond, one must first examine the definitions of fundamentalism and terrorism, as well as their historical ties. In addition, understanding the dynamics between religion, politics, and society become important to place the nature of the violence into the correct context. Finally, one must determine the shift from nationalistic violence to fundamentalism, and use this to explain how fundamentalism has become the root of modern terroristic acts.

To define terrorism is akin to attempting to define any human experience, if only in the fact that terrorism defines itself to each person differently. Socio-political realities, religious affiliation, and cultural identification play into an individual's definition, creating difficulties in expression within universally understood terms. In each instance of terrorism (regardless of definition) one might view an act as "terroristic" while another may not. If a hard and fast definition must be constructed, it should be simple and open to interpretation. We know the following: terrorist acts are violent (or at least inherently dangerous), typically involve more than one target, and are perpetrated to initiate change (whether societal, political, religious, or ideological). 


\section{Journal of Terrorism Research}

Therefore, one may choose to define an incident as an act of terrorism if the violence or the threat of violence was used against more than one person in order to instigate change on a societal, political, religious, or ideological level.

Fundamentalism, however, is much easier to define. Simply put, it is an unwavering faith to a religious belief system, though some assert that the term 'fundamentalism' is another way of excusing 'normal' religion and isolating problems into a deviant form of the doctrine (Juergensmeyer, 2004). Though originally used to describe certain sects of Christianity, this strict adherence to theoretical doctrine has stretched to include all major world religions. Multiple terrorist acts have been committed by "followers" of other religions; specifically, due to current developments and acts committed by the Islamic State of Iraq and the Levant (ISIL), this examination will focus on Islamic fundamentalism. Whether through the original political split inside of Islam or the eventual Shiite-Sunni split that has led to numerous conflicts, Islam has been in almost constant turmoil since its appearance, with fundamentalism and radicalization inside of its doctrine becoming a mitigating factor in most of the terrorist acts completed within the $21^{\text {st }}$ century (White, 2012). With these definitions in mind, examining the historical background of both terrorism and fundamentalism will provide a context in which to place the influence of religious terrorism on politics and society.

\section{Historical Background}

The word 'terrorism' first originated during the French Revolution (1789-1799) and was used to describe the government; by 1848, it was used to describe violent revolutionaries (White, 2012). By the end of the 1800's and early 1900's, the meaning had again changed to describe the violent acts of several organized groups, such as labor organizations, anarchists, nationalistic groups, and ultra-nationalistic political organizations. Eventually, nationalism became the main motivation behind acts of terrorism; however, a clear shift had already begun as religion came to the forefront of terroristic reasoning.

According to Hirschmann (2000), five types of terrorism now exist: ideological, involving the desire for revolutionary changes within political or social structures; ethno-political, in which ethnic minorities long for their own state within an existing state or some degree of political and cultural autonomy; religious, where a desire to impose religion-based norms of conduct appears and can evolve into apocalyptic fanaticism; single issue, involving the extremist militancy of groups/individuals protesting a perceived grievance; and "chosen ones", who are mentally disturbed/deranged individuals with a certain mission or social philosophy who are not connected to a network (pg. 299). All things considered, one could make a justifiable argument that while all "types" of terrorism are equally valid in their need for examination, in light of recent events religious motivations stand in the forefront and require immediate consideration.

This shift has been attributed to increasing amounts of acts involving religious terrorism to political Islam, Christian fundamentalism, and Messianic Zionism (Bergesen \& Lizardo, 2004). As terrorist ideologies have become more religious, terroristic violence has become more indiscriminate and targets appear to be more geographically dispersed. In regards to fundamentalism, groups wishing to have their religion practiced purely are called fundamentalist, as are groups pushing for an overhaul of the national or global political system with a cultural connection to a religion (Emerson \& Hartman, 2006). While first used to describe a conservative strain of Protestantism developed in the United States, the fundamentalist 'battle' was not so much with the secular state as it was between other Protestant people and organizations; however, other organizations and sects were attempting to modernize, with fundamentalists becoming militantly opposed (Emerson \& Hartman, 2006). 


\section{Journal of Terrorism Research}

While this conflict eventually died out, and fundamentalism relatively disappeared until the 1970's, some have stated that without modernization and secularization there would be no fundamentalism; when resurgence did occur in the 1970's, it appeared more politically active than before, and was beginning to be observed as part of most of the world's religions (Emerson \& Hartman, 2006). Considering the shift that occurred, religious fundamentalism then came to been seen as an aggressive politicization of religion for the pursuit of nonreligious ends, being only a superficial form of terrorism or extremism; this definition fits more clearly with what fundamentalism has become in the late $20^{\text {th }}$ and early 21 st centuries (Tibi, 1998).

When examining historical ties between terrorism and fundamentalism, one can look at the developed ideological and organizational requirements of modern fundamentalism from Emerson and Hartman (2006), which closely resemble the process of radicalization and indoctrination of an individual into a terrorist organization described by White (2012). Ideological requirements for modern fundamentalism include defense of tradition, selective choice in doctrine, dualistic morality, absolutism, and messianism (Emerson \& Hartman, 2006). This clearly connects with the organizational requirements, including an elect/ chosen membership, set boundaries for inclusion, "chosen" leaders, and behavioral requirements. White (2012) describes the process of radicalization as involving an alienated young man, who upon meeting other alienated young men forms a group. From there, the group gravitates towards religion, and attempt to outdo each other in their zeal for the cause. The religion then begins to be interpreted in militant terms- while most groups stop at this point, some continue development leading to a militant group that encounters a terrorist contact, and join the terrorists through a group decision (White, 2012). Keeping in mind these ties of organization, the religio-political and socio-political discourses regarding fundamentalism and terrorism can now be examined.

\section{Religio-Political and Socio-Political Discourse}

First, one must note that while most think of Islam and politics as synonymous, terrorist attacks are driven by Islamic extremists and political Islam stands separate from that extremism, though they are just as disillusioned by with the Western World (Ayoob, 2004). In fact, many Muslims become upset when their faith is portrayed in terms of violent terrorism, as the majority of the violence seen with Islamic fundamentalists should be attributed to the religio-political environment instead of the religion itself; in those states where religious freedom is allowed and/or encouraged, violence is rare and becomes limited to isolated incidents, as opposed to the violent religious groups that continue to emerge in countries where the state suppresses religious freedom or espouses one religion over another (Emerson \& Hartman, 2006; White, 2012).

Specifically focusing on al Qaeda, some question the idea of the organization being fully religious, and instead define it as a violent political organization that attempts to hide behind Islam; while the doctrine of Islam is usually described as peaceful and tolerant by religious scholars, the basic mission of al Qaeda is to create a popular uprising that will destroy Western influence and reestablish the caliphate system (Hart, 2008, in White, 2012). Bin Laden, as the leader of al Qaeda, adopted the philosophies of Abdullah Azzam, who believed that Islam had been dominated by foreign powers for far too long; this was seen as an opportunity to wage a 'holy war' against the United States, the West, Israel, and Muslims who opposed jihadist theology (White 2012). After declaring war on the United States in 1996, bin Laden had his religious council issue two religious fatwas in 1998 in order to validate his opposition of the Western world; since that time, al Qaeda has completed many terrorist attacks on the world stage, though its capabilities to do so have been slightly diminished (Sageman, 2009, in White, 2012; White, 2012). 


\section{Journal of Terrorism Research}

Radical religious movements based in cultures of violence have been found to contain three commonalities: rejection of compromises with liberal values and secular institutions, refusal to observe boundaries that secular society has set upon religion, and attempts to create a new form of religiosity that rejects what they regard as weak, modern substitutes for their religion's origin (Juergensmeyer, 2011). In the case of religious extremism, rules that cause members to conform in ways of behavior, violence, intolerance, and self-destruction to achieve the group's goals work to legitimize their interpretation of religious doctrine (Pech \& Slade, 2006). Furthermore, these groups hide within cultural and religious shadows with a sense of justification, eschewing the political goals of social order and community, and vehemently oppose the dominant political power; from a 'terrorist' point of view, they are waging jihad, which legitimizes any action perpetuated against mankind, even if it is forbidden in the mainstream form of Islam (Pech \& Slade, 2006). Therefore, one could argue that the need for religion sprung from treachery observed in societies around them, as the modern secular world caused them to feel victimized and abandonment of religion in such a world would mean a loss of their own individual identities; by fashioning a 'traditional' (fundamentalist) religion of their own making, they created an outlet to express the concerns they had not only with their religious/ethnic/national communities, but with their own personal selves (Juergensmeyer, 2001).

While 'religious terrorists' may have anti-modern goals and strive to return society to an idealized past therefore making them anti-democratic and anti-progressive, there is another viewpoint contending that terrorism can be seen as a socio-political phenomenon that difficult to define objectively and universally, being that it is largely context-based (Bhatia, 2009; Gunning \& Jackson, 2011). When observing religious terrorism from their own political perspective, it may be possible that communities affected by poverty, underdevelopment, and fragility of state are breeding grounds for dissatisfaction, and lead to potential violence with the realization of extremism through acts of terrorism (Pech \& Slade, 2006). Additionally, though this argument is focused on rise of religious fundamentalism and its acceleration of terrorism, the possibility exists that religion might not be the primary cause of this acceleration.

Furthermore, structural factors that have been known to be key drivers in political factors might have a huge influence in the Middle East, as it is a war-torn region with state repression, political exclusion, and horizontal inequality; a long transition of transnational non-state networks rooted in socio-religious structure then provides extensive funding opportunities for extremism (Gunning \& Jackson, 2011). In addition, economic and social tensions experienced by large numbers of people were not religious, and instead were issues of social identity and participation; however, these secular ideological expressions of rebellion were replaced by ideological formations that are religious (Juergensmeyer, 2004). This replacement becomes evident through the shift from nationalism as the underpinnings of terrorism to religion as seen in modern times.

\section{From Nationalism to Fundamentalism}

Acts of murder on behalf of a moral code has traditionally been a political statement, and bringing religion into the field breaks the state's monopoly on this morally sanctioned killing (Juergensmeyer, 2001). This works to support the notion that nationalism has been replaced as the underpinnings of terrorism in recent times. As mentioned previously, the word 'terrorism' was originally ascribed to violent revolutionaries, political groups, and nationalistic groups- why, then, has the shift to religious reasoning occurred? This could be attributed to the decline of political and oppositional resistance in many modernized countries, most likely due to the loss of political capabilities; in the Western world, democratic societies have lessened the need for 


\section{Journal of Terrorism Research}

political action, and the resurgence of religion plays a large part in the decline of nationalistic terrorism (Ross \& Gurr, 1989). From a Marxist point of view, the modernization of society should cause a decline in religious identification; however, it seems that the opposite is true, and some even state that without modernization and secularization there would be no fundamentalism (Emerson \& Hartman, 2006; White, 2012). A possible cause, at least in the context of Islamic fundamentalism, could be that religious authority can provide a readymade replacement for secular authority, so the attempt becomes to challenge the legitimacy of the secular authority and gain support on the basis of religion (Juergensmeyer, 2001). This religiously motivated political shift works to further the goals of the terrorist extremists.

Furthermore, the link between religion and terrorism can be inferred from a statistical observation that 'religious terrorists' have been more violent than their secular counterparts in recent decades, causing a major shift from left-wing and anti-colonial violence towards religiously inspired violence in recent times (Gunning \& Jackson, 2011). With an increasing presence of violent eschatology, a group believing it must wage war to purify the Earth before the return of a deity becomes a defining factor in the 'religious' terrorism of the modern day- for example, the idea of a holy jihad against the West by Islamic fundamentalists has become the driving force behind violent attacks in the past few decades (White, 2012). From 1980 onward, religious groups were responsible for ever-increasing violent conflicts in comparison to non-religious nationalist groups, allowing one to argue that the new 'religious' terrorism is due to the increasing prevalence of religion in the ideology of terrorist organizations, subsequently working to influence the increase of indiscriminate violence (Bergensen \& Lizardo, 2004; Fox, 2004).

\section{Fundamentalism and Terrorism}

When looking at how fundamentalism has accelerated terrorism, one must consider the effect fundamentalism has had on modern day terrorism. To begin, many scholars claim that 'religious terrorists are more dangerous', and that with strong religious beliefs comes the increased likelihood of conflict, even going so far as to state that the term 'religious terrorism' insinuates an implicit relationship between religious ideas and violence (Emerson \& Hartman, 2006; Enders \& Sandler, 2000; Fox, 2004; Gunning \& Jackson, 2011; Juergensmeyer, 2001; Pearce, 2005; White, 2012). Religious terrorism produces radical value systems, different methods of legitimation and justification, skewed morality, and subsequently may be a more lethal threat than that posed by traditional terrorists (Hoffman, 2006, in Gunning \& Jackson, 2011). Development of a more symbolic nature of religion could bring about an emphasis on sacrifice and cosmic war as a means to achieve their specified end; in recent years, a terrorist incident is almost $17 \%$ more likely to result in death or injuries, with this increase in severity specifically attributed to the growth of religious terrorism (Enders \& Sandler, 2000; Juergensmeyer, 2003). From a more historical perspective, the most basic reason for terrorism is to gain recognition or attention- the theatricality of modern terrorist attacks exemplifies this (Crenshaw, 1981). As the level of violence works to spread the publicity of the event, this direct combination working with religious motivation provides yet another reason why terrorism has been accelerated by fundamentalism.

Modern considerations of religious terrorism can be summed up very simply-current times have observed actions that become "terror for the sake of terror", i.e. acts that are intended to cause chaos and confusion, not to legitimize or push a political ideology (White, 2012). Though this assumption may or may not be correct, there have been events that could be perceived in this light. If one is to assume this idea is true, it could provide support the idea of religious terrorism being more deadly than 'traditional' terrorism, with the 


\section{Journal of Terrorism Research}

assumed 'willingness' to kill larger numbers of people indiscriminately due to their religious perspective; for example, the World Trade Center assault had no obvious military or political goal, and could be considered a perverse performance of power intended to shock the world and draw people into their idea of a 'cosmic war' (Hoffman, 2006; Juergensmeyer, 2001). With an image of the perceived 'cosmic war', those engaged in the conflict have wildly different perspectives from other types of terrorism; by absolutizing the conflict and demonizing opponents, compromise becomes extremely difficult, as the fundamentalists hold out for the promise of total victory through divine intervention and strict adherence to these interpretations leads to violence in the minds of members (Juergensmeyer, 2001; Pech \& Slade, 2006).

When regarding the lethality of religious terrorism, one must consider the prevalence of suicide tacticswith the terrorist knowing that they will die because of the act, the idea of self-sacrifice and great reward empower him/her to take more risks and be more destructive, as they are more likely to succeed (Wade \& Reiter, 2007). Terrorist groups build new mythologies to justify their actions, and these most often include self-sacrifice or death, leading members to seek martyrdom and terror as their way of life and very existence becomes threatened by peace; this in itself could lead to increased violence, as the member committing the act of terror has no fear of repercussion from authorities (Stern, 2003). More support for an increase in violence with religious terrorism is found by the observation that the goals are not short-term, and the terrorists perpetuating these acts might not (and don't expect to) live to see their goal accomplished- their fight is for God (in whatever form), and the rewards are vast for those who aid in the struggle- in other words, by 'spiritualizing' violence, religion accelerates terrorism and gives it more power (Juergensmeyer 2001). Subsequently, religion brings new aspects to conflicts in several ways- by personalizing the conflict, rewarding those engaged (transcendently or otherwise), lack of mobilization directed only at social or political issues, organizational networks, a sense of moral justification for political encounters, and a justification of violence that challenges the state (Juergensmeyer 2004).

\section{Conclusion}

By looking at the definitions and historical ties of fundamentalism and terrorism, exploring the religiopolitical and socio-political discourse relating to Islamic fundamentalism, and examining the shift from nationalistic terrorism to religious terrorism, one can better understand the reasoning presented to argue that fundamentalism has, in fact, accelerated terrorism in the modern world. As the severity of attacks increase, scholars will continue to examine the why of the situation in order to understand the motive behind the violence and attempt to determine if any actions could intercept or stop the violence. However, there will always be conflict, especially with religion; historically, religious conflict has experienced its share of rise and fall through the centuries, and our current time is no different. The focus, then, shifts from understanding why religious terrorism has escalated and accelerated terrorism to figuring out how to properly prepare and respond to such attacks, as well as develop ways to prevent such attacks. Unfortunately, the reality of the situation stands to reason that there will be no end to the conflict and violence, nor terrorism itself. Many countries are still vastly underprepared to deal with a terrorist attack of even moderate destruction. Preparation and response must be the focus of both scholars and governments alike; once the proper precautions are in place, prevention may become the focal point of research.

About the author: Cassandra Rausch, $M S$ is currently a doctoral student in the Department of Criminal Justice at the University of Louisville, Kentucky who focuses on bringing interdisciplinary perspectives into 


\section{Journal of Terrorism Research}

the discipline, particularly anthropological methods. While her main areas of research are policing and death investigation, she also examines issues regarding genocide, terrorism, and mass disasters. Through domestic and international conference presentations and journal publications, she hopes to enrich the literature regarding these topics and provide recommendations for new directions in the field.

\section{References}

Ayoob, M. (2004). Political Islam: Image and reality. World Policy Journal, 21(3), 1-14.

Ben-dor, G., \& Pedahzur, A. (2004). The uniqueness of Islamic fundamentalism and the fourth wave of international terrorism. In A. Pedahzur \& L. Veinberg (Eds.), Religious fundamentalism and political extremism (71-90). Portland, OR: Frank Cass \& Co. Ltd.

Bergensen, A.J., \& Lizardo, O. (2004). International terrorism and the world-system. Sociological Theory, 22(1), 38-52.

Bhatia, A. (2009). The discourses of terrorism. Journal of Pragmatics, 41, 279-289.

Crenshaw, M. (1981). The causes of terrorism. Comparative Politics, 13(4), 379-399.

Emerson, M.O., \& Hartman, D. (2006). The rise of religious fundamentalism. Annual Review of Sociology, 32, 127-144.

Enders, W., \& Sandler, T. (2000). Is transnational terrorism becoming more threatening? A time-series investigation. Journal of Conflict Resolution, 44(3), 307-332.

Fox, J. (2004). The rise of religious nationalism and conflict: Ethnic conflict and revolutionary wars, 19452001. Journal of Peace Research, 41(6), 715-731.

Gunning, J., \& Jackson, R. (2011). What's so 'religious' about 'religious terrorism'? Critical Studies on Terrorism, 4(3), 369-388.

Hirschmann, K. (2000). The changing face of terrorism. Internationale Politik und Gesellschaft, (3), 299-310.

Juergensmeyer, M. (2001). Terror in the name of God. Current History, 100(649), 357-360.

Juergensmeyer, M. (2003). Terror in the mind of God: The global rise of religious violence. University of California Pr.

Juergensmeyer, M. (2004). Is religion the problem? Hedgehod Review, 6(1), 1-10.

Pearce, S. (2005). Religious rage: A quantitative analysis of the intensity of religious conflicts. Terrorism and Political Violence, 17(3), 333-352.

Pech, R.J., \& Slade, B.W. (2006). Religious fundamentalism and terrorism: Why do they do it and what do they want? Foresight, 8(1), 8-20.

Radojevic, K. (2002). Religion and terrorism. Religija I Tolerancija, 8(14), 239-252.

Ross, J.I., \& Gurr, T.R. (1989). Why terrorism subsides: A comparative study of Canada and the United States. Comparative Politics, 21(4), 405-426.

Stern, J. (2003). Terror in the name of god: Why religious militants kill. New York, NY: Harper Collins.

Tibi, B. (1998). The challenge of fundamentalism: Political Islam and the new world disorder. Berkeley, CA:

University of California Press. 
The Centre for the Study of Terrorism and Political Violence

\section{Journal of Terrorism Research}

Wade, S.J., \& Reiter, D. (2007). Does democracy matter? Regime type and suicide terrorism. Journal of Conflict Resolution, 51(2), 329-348.

White, J.R. (2012). Terrorism and homeland security ( $7^{\text {th }}$ ed.). Belmont, CA: Wadsworth, Cengage Learning. 